Språkspalten

\title{
Tallenes tale
}

\begin{abstract}
Det finnes ingen faste regler som sier at man alltid skal skrive noen tall med sifre og andre med bokstaver. Vanligvis er det slik at de små skrives med bokstaver, men dette praktiseres ulikt i ulike redaksjoner. I forfatterveiledningen kan du finne ut hva som er praksis i Tidsskriftet.
\end{abstract}

Tallord. Grunntall til og med ti skrives med bokstaver, fra og med 11 skrives de med sifre i løpende tekst, f.eks.:

tre pasienter, 14 pasienter

men

tallene $2-12$

Ordenstall skrives med arabiske tall og punktum etter, f.eks.: 1. (første), 33. (trettitredje) eller med bokstaver.

Ordenstallet for 0 (null) skrives 0 -te eller nulte. Merk også n-te, n-te-gradslikning.

Romertall skrives uten punktum, f.eks.: Harald V

Ved nummerering brukes tall, f.eks.:

dag 3 , side 5

Fotnoter merkes også med tall (ikke stjerner), f.eks.:

${ }^{1} \mathrm{p}<0,01$

${ }^{2} \mathrm{p}<0,001$

Ved talluttrykk brukes både særskriving og sammenskriving, f.eks.:

fem års alder, men femårsalderen

12 års alder, men 12-årsalderen

fire ukers ferie, men et ettårsmateriale, to femårsperioder tiårsgrupper tiårs aldersgrupper

Ved talluttrykk med benevning brukes tall, f.eks.:

$6 \mathrm{~kg}$

kr 150 eller 150 kroner

kr 15,30

kr 14,00

Ved bruk av tall i forbindelse med kroner brukes utelukkende tall, også for dem under 10:

5 kroner og 2 millioner kroner.

Ved desimaltall brukes komma (ikke punktum), f.eks.:

$\mathrm{Hb} 12,8 \mathrm{~g} / 100 \mathrm{ml}$

Substantivets tall ved brøk og desimaltall, f.eks.:

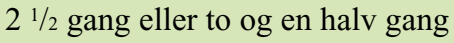
men 2,5 ganger

Brøk, f.eks.:

$1 / 3$ eller en tredel

$1 / 4$ eller en firedel
Gangetegn

Prikk ved matematiske angivelser, f.eks.: $8 \cdot 9=72$

Trombocytter $125-400 \cdot 10^{9} / 1$

Tegnet $\times$ ved formater og pakningsstørrelser, f.eks.:

Maleriet måler $90 \times 120 \mathrm{~cm}$

Endose: $2 \times 49$ stk.

Tall fra og med 1000 skilles ut med mellomrom, f.eks.:

3600

$2-4000$ (= to til fire tusen)

$2000-4000$ (= to tusen til fire tusen)

Flere språkråd finner du på www.tidsskriftet.no/index.php? nota_id $=540$

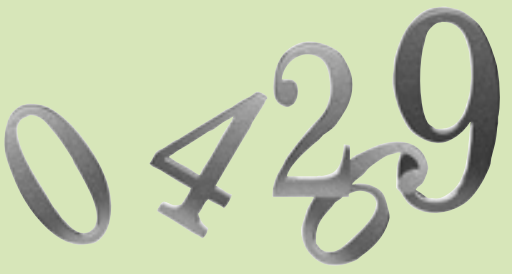

\section{Kjært barn...}

Navn på statlige institusjoner skal være i henhold til Språkrådets normer. Prinsippet for institusjonsnavn er stor forbokstav i første ord og små i de neste. Heretter vil dette bli praktisert strengere i Tidsskriftet.

Fra og med nr. 1/2009 vil vi skrive sykehusnavnene slik det blir anbefalt i Statsspråk (1). Det vil da hete Haukeland universitetssykehus, Stavanger universitetssjukehus og St. Olavs hospital.

1.12. 2008 ble Oslo universitetssykehus HF stiftet. Det består av de tidligere Aker universitetssykehus, Rikshos- pitalet og Ullevål universitetssykehus. Hvordan tilhørighet til en av disse eventuelt skal markeres, er ennå ikke klart.

\footnotetext{
Litteratur

Slik skal navnet skrives. Statsspråk 2008; nr. 2: 2.
} 